peculiar, so far as I can discover, to this manuscript and to. William of Malmesbury. May we not, in the face of this cumulative evidence, hold that be is the Willelmus of the verses prefixed to this volume, whether they be written in his hand or that of another?

W. H. Stevenson.

\title{
An Unpublished Life of Edmund Rich.
}

The medieval biographies of Edmund Rich are tolerably numerous. No fewer than three were printed by the late Dom Wilfrid Wallace in the appendices to his valuable St. Edmund of Canterbury (1893). These have some obvious affinities, and all of them are to a greater or less degree founded upon the same stock of materials which was employed by the author of the better known Pontigny life. This work, which dates from the middle of the thirteenth century, is printed in the third volume of the Thesaurus Novus of Martène and Durand; from it are derived the life printed by Surius, ${ }^{1}$ that by Vincent of Beauvais, ${ }^{2}$ and that by John of Tynemouth. ${ }^{3}$ There is, however, another life, which has never yet been printed. It is of about the same date as the Pontigny life. It exists in three English copies-Balliol College MS. 226, Lambeth Library MS. 135, Cambridge University Library MM. 4.6,-all of the thirteenth century. For convenience we may call it the Balliol life. It has been used by the two most recent biographers of St. Edmund, Dom Wallace and the baroness de Paravicini. But they differ in their opinions as to its nature and value. Dom Wallace ${ }^{4}$ came to the erroneous conclusion that it was a copy of the Pontigny life. The error was natural, for large sections of the two works. are verbally identical. But, as the order of the sections varies. considerably, and as each life contains facts which are not recorded by the other, it is necessary to suppose that the two writers followed a common source or set of sources. The baroness de Paravicini, ${ }^{5}$ on the other hand, overrates the difference between the two lives. Rejecting Martène's hypothesis that the Pontigny life was composed by Bertrand of Pontigny, the saint's chamberlain, she. credits Bertrand with the Balliol life on the strength of passages which occur in both lives, but which, through some oversight, she regards as indisputably the work of the Balliol author.

The true relation of the Balliol and Pontigny lives may be-

3 De Probatis Sanctorum Historiis, vol. vi. ed. 1575.

2 Speculum Historiale, bk. sxxi.

${ }^{3}$ Nova Legenda Angliae, vol. i., ed. Horstmann, 1901.

- St. Edmund of Canterbury (1893).

s St. Edmund of Abingdon (1898). 
measured by a systematic collation of their texts. Such a collation we give below, printing in full those passages which are peculiar to the Balliol life. For this collation the Balliol manuscript has been used. It is fully described in Coxe's catalogue (i. 71); we need only remark that the scribe, though an artistic penman, was rather careless and unintelligent. The numbers which we prefix to the sections do not exist in the manuscript, but are added for convenience of reference.

Ball. Coll. MS. cesxvi. fo. $47, \nabla^{\circ} b-f o .64, r^{\circ} b$.

Prologue. Ad honorem Salvatoris ... habuerat in talentis. Proposite vero actionis narrationes veritatis gesta sunt.

The Pontigny life, as printed by Martène and Durand, has no prologue. The Balliol prologue reappears in the life attributed by Dom Wallace to Robert Rich; this life will be found among Dom Wallace's appendices. ${ }^{6}$ The natural conclusion is that it is the prologue found in a source common to all three writers, since the 'Robert Rich' life is certainly not derived from the other two, nor they from it.

$\S 1$. Birth and parentage of St. Edmund. Abbreviated from tho narrative in $\$ \S 1-4$ of the Pontigny life.

\$2. Quomodo comam monente matre deposuit. Abbreviated form of the Pontigny life, $\$ 5$.

$\S \S 3,4$. De morte matris. Quomodo due sorores eius facte sunt moniales $=$ Pontigny life, $\S 7$, but more shortly, with a change in the order of narration. The Balliol MS. gives the name of Catesby Priory correctly; the Pontigny life gives Keteby. The common source, for Edmund's sisters; used the deposition (veriloquinm ac breviloquium) of Robert Bacon, which is quoted in a life printed by Dom Wallace (p. 561).

$\S \S 5$, 6. Quomodo apparuit ei dominus Ihesus = Pontigny life, $\S 6$. The general correspondence is striking, though there are differences of phraseology, and each writer adda his own reflexions. There can be little doubt that each is here following the authority of Bertrand the archbishop's chamberlain. The Pontigny life says, ' Scit enim hoc qui vidit et scripsit haec et super eis perbibet testimonium, nee est de eius testimonio leviter alicui dubitandum; dum enim nocte quadam pro more cubicularii in camera cum illo consistens nomen illud gloriosum fronti suae diligenter eum imprimere conspiceret,' \&c. The Balliol writer says 'ut ipse testimonium perhibet qui vidit et scripsit hec. Et scimus quia verum est testimonium eius.'

$\S 7$. Qualis fuerit in puericia in scolis $=$ Pontigny life, $\S 9$. Here, as elsewhere in all passages which offer an opportunity for moralising, the Pontigny writer improves the occasion.

\$ 8. Quomodo vidit animam cuiusdam a demonibus raptam $=$ Pontigny life, $\S 8$. Two significant differences may be noticed. The Balliol writer begins, 'Quadam die cum iter ageret versus Habendoniam una cum illo comite vie,' \&c. This companion is treated as some one who has been already mentioned. But no such companion has been 
mentioned. This is one of the fairly numerous cases in which we find reason to suspect that the Balliol writer is abridging without intelligence from a fuller source. The Pontigny life, following the same source, says, "Die quadam cnm versus natale domicilium, videlicet Abbendoniam, iter ageret cum alio quodam quem secum habuit itineris socium,' \&c., and so avoids the difficulty. The other point to be noticed is that the Balliol life names a definite place, Chalgrove, as the scene of the vision, whereas the Pontigny writer, who has no liking for English names, speaks of 'the nearest village' without specifying further.

\$9. Quomodo carnis integritatem servaverat. A short paragraph identical with a passage in the Pontigny life, $\$ \mathbf{9}$.

$\$ 10$. Quomodo ymaginem beatae Virginis desponsaverat filius accrescens $=$ Pontigny life, $\$ 10$, but with different moralisations.

\$11. Quomodo verberavit quandam puellam = Pontigny life, $\$ 11$.

$\S$ 12. De quadam maritata cum provocante ad licita (sic for illicita?) $=$ Pontigny life, $\S 12$.

$\S \S 13,14$. Item temptatio de alia. Quod respondit familiani se increpanti. These two anecdotes are told in the Pontigny life, $\$ 51$. The second belongs to the period of Edmund's pontificate; for the friend who rebuked him was, as we learn from another souree, no other than Richard de la Wych, who became Edmund's chancellor after the saint was appointed to Canterbury: The Pontigny life, therefore, gives the anecdote in its proper chronological setting. The Balliol writer transfers it to the early part of his book, in order to place it in juxtaposition with another story of the same kind.

$\S 15$. Quali cilitio utebatur $=$ Pontigny life, $\$ 13$. The two accounts agree closely, even to their wording; but the Pontigny writer adds an anecdote to explain how it was that these austerities, which Edmund so carefully concealed, became generally known.

$\$ 16$. Quod ignis non potuit comburere cilicium eins. A story which is repeated in the Pontigny life, $\S 47$. In both cases the authority is quidam cubicularius, who is no doubt to be identified with Bertrand of Pontigny.

\$17. Quomodo legenti arismetican apparuit mater eizs. These anecdotes are given in the Pontigny life, $\$ \$ 14,16$. The first part of this section describes the piety which he displayed as a master of arts in Oxford. Here the common source is a letter from the University of Oxford to Innocent IV, which is printed by Martène and Durand (Thesaurus Novus, iii. col. 1839) ; the letter, so far as it is of a narrative character, is transcribed in both lives.

$\S \S 18,19$. Qualcs habuit in scolis auditores $=$ Pontigny life, $\$ \$ 16$ (last sentence), 17. Here we are able to prove that the Balliol text keeps more closely than that of the Pontigny MS. to the words of the common source. For the common source is the deposition of Robert Bacon as quoted by the author of the Cottonian MS. Julius D. vi (1), a life which Dom Wallace prints. The relevant passage will be found at p. 563 of Dom Wallace's work. This Cottonian life, which the baroness de Parsvicini is probably right in ascribing to Matthew Paris, is very largely based upon the depositions which were collected with a view to the process of canonisation. 
§20. Quomodo apparnit ei Spiritus sanctus = Pontigny life, $\S 18$, much condensed.

$\S 21$. Qualis fuit in predicatione = Pontigny life, $\$ 19$ (beginning). The Pontigny writer adds, however, some interesting particulars respecting the saint's intimacy with William Longespée and his manner in preaching.

\$22. De quadam peccatrice conversa. This aneclote occurs in the Pontigny life, $\$ 19$.

§28. Quonodo apparnit ei beatus Iohannes = Pontigny life, $\$ 15$, where another anecdote is added to show the perseverance of St. Edmund in prayers and other spiritual exercises. half).

\$24. Quomodo verberavit diabolum = Pontigny life, \$19 (second

$\$ 25$. Qualis fuit in studendo $=$ Pontigny life, $\$ 30$. This desoription of the saint's lecture room evidently comes from one who had seen it, and can scarcely be the work of Bertrand, who was only the companion of his later years.

§ 26. De abstinencia beati Eadmundi. This section brings together a number of facts which are scattered over $\$ \S 20-3$ of the Pontigny life. The common original used the deposition of Robert Bacon, to which we have already referred (above, $\S \S 3,18$ ).

$\S 27$. Quomodo dilusa sit iusti simplicitas. This anecdote, not to be found in the Pontigny life, runs as follows: 'Cum quadam nocte apud quendam nobilem hospitaretur, more suo parum comedit et bibit et ante lectum suum iacuit. In crastino pro recessu eius quidam de familia cameram qua iacuerat ingressi, et nullam formam hominis in lecto suo videntes dixerunt ad invicem, Ecce quam ebrius fuit vir ille nocte qui pre ebrietate lectum suum adire nescivit.' The same story occurs in one of the lives printed by Dom Wallace. ${ }^{7}$

$\$ 28$. De conversatione eins posiquam ad theologiam se contulit. These anecdotes are given, in much the same terms, in the Pontigny life, \$ 23-5.

\$29. Quod placitis non interjuit. Three anecdotes are given to illustrate the saint's unvorldliness. They occur in the Pontigny life, \$§ 26 (the saint's abstention from law courts), 14 (his contempt for money), 15 (his insistence upon chastity among his servants). The common source drew the two latter anecdotes from Robert Bacon's deposition.

§ 30. Cum quibus elegit conversari $=$ Pontigny life, $\$ 28$. The common source followed, for the first part of this section, a letter from the canons of Merton to the pope, which is printed by Martène and Durand. ${ }^{8}$ For the second half, relating to the saint's stay at Combe Abbey (co. Warwick), it is probable that a similar letter from the monks of that house was used.

$\S 31$. De nobili facto quod fecit Parisius tempore famis. The same anecdotes are given in the Pontigny life, $\$ \S 16$ (how he sold his books to relieve the famine-stricken), 14 (how he paid a poor scholar's physician; but the Pontigny life places this incident at Oxford), 29 (his hospitality).

\$32. Quomodo scolari suo infirmo scrvivit $=$ Pontigny life, § 14 .

? Op. cit.p. 604.

B Op. cit. col. 1899. 
The story comes from the deposition of Robert Bacon. ${ }^{9}$ The incident bappened when St. Edmund was a regent in arts at Oxford. It is given by the Pontigny writer in the proper chronological sequence, but transferred to a later place by the Balliol writer, in accordance with his general principle of grouping anecdotes by reference to their subjects. A passage about the saint's simplicity which comes at the end of this section in the Balliol life is reproduced in $\S 30$ of the Pontigny life.

\$33. Quomodo legationcm crucis suscepit $=$ Pontigny life, $\$ 34$. When canon and treasurer of Salisbury St. Edmund received a papal commission to preach a crusade (c. 1227). Both lives proceed to give an account of the miracles which were wrought in the course of the circuit which he made for this purpose through the counties of Somerset, Gloucester, Hereford, Worcester, and Oxford. These miracles fill §§ 34-9 of the Balliol life.

$\S$ 34. De manu cuinsdam mulieris contracta et per eum sanata $=$ Pontigny life, $\S 35$, where the scene of this miracle is placed at Leominster.

$\S 35$. De moniali de Boklond = Pontigny life, $\S 36$, which gives the name of the convent as Boklande-perhaps Minchin Buckland, in Somerset.

§§ 36-8. Quomodo impetum imbrium irruencium dum predicaret compescuit, \&c. Three cases in which rain was miraculously prevented from interrupting his sermons. The Pontigny life, $\S \S 38-43$, gives these and other similar cases.

§39. Quomodo candela non potuit comburere bibliam eins $=$ Pontigny life, $\S 44$.

$\S 40$. De quodam scolari per eum sanato. The story (how St. Edmund by means of prayers transferred to himself the ailment of a pupil) is told in the Pontigny life, $\$ 14$, as an incident of his early Oxford life. Here the common source quoted the deposition of Robert Bacon, which is reproduced more accurately in the Balliol text. This is one of the sections which shows most conclusively that the Balliol life is not derived from the Pontigny life.

$\S 41$. De visitatione alterinu $=$ Pontigny life, $\S 33$.

$\S 42$. De luce sibi divinitus reddita = Pontigny life, $\S 45$. In relating this curious little anecdote the Balliol author has preserved the correct reading of a rare word (crucibulum $=\mathrm{a}$ hanging lamp), which so puzzled the Pontigny scribe that he substituted for it the common cubiculum, which in this context is unmeaning. The Balliol text runs, - Sedens aliquando ad crucibulum suum casu obdormivit; et ecce mus intrans in crucibulum cauda sua illud extinxit. Cumque evigilasset et lumen extinctum reperisset, suspirans ingemuit et ait, Ha sancta Maria, et subito lumen in crucibulo reparatur.'

\$ 43. Quomodo antracem in proprio pede curavit = Pontigny life, $\S 46$. In describing the ulcer (antrax) from which the saint once suffered the Balliol author glosses the Latin with the French name: 'accidit morbo quodam qui Gallice dicitur li felum in pede gravari.' Here and in one other place $(\S 49)$ he assumes that French will be more

9 Wallace, op. cit. p. 564. 
intelligible to his readers than Latin, while, on the contrary, he glosses his English quotations in Latin.

$\S 44$. Quod nullum genus vermium in vestibus eius potuit reperiri $=$ Pontigny life, $\S 47$. For this singular mark of holiness both authors vouch the authority of the saint's chamberlains; probably Bertrand of Pontigny is the source. The Pontigny writer adds the remark, 'nec immerito istud descripsimus pro miraculo, cum vix ullus vel certe nullus hoc probro careat vel tormento.'

$\S 45$. Quomodo electus est in archiepiscopum = Pontigny life, §§ 48, 49. The two accounts are substantially the same, and evidently the original source was a domestic of the archbishop's household. An incidental proof of its accuracy is afforded by the statement that Edmund was, at the time of his election, residing at Calne; we know from the Sarum archives that the benefice of Calne was attached to the office of treasurer of the cathedral, which he then beld.

$\S 46$. Qualis fuit in archiepiscopatu=Pontigny life, § 50 . The common source followed a letter from the abbot of Reading, or some narrative quoted by the abbot; his letter is printed by Martène and Durand..$^{10}$

$\S \S 47-8$. De opere misericordie quod exercebat, \&c. Instances of his goodness to the tenants of the archiepiscopal estates; reproduced in Pontigny life, § 52 .

$\S \S 49-50$. Quod munera non accipiebat $=$ Pontigny life, $\S 53$. Here the Balliol life gives in French a mot of the archbishop, which the more formal Pontigny writer latinises. St. Edmund used to say, 'Entre prendre et pendre ni ad ke une lettre. Dunt cil ke prent volunters est mut pres de pendre.' There can be no doubt that this is nearer to the original source than the Pontigny report: 'Prendre et pendre non differunt nisi una littera, unde patet quod valde proximus est suspendio qui munera libenter accipit nisi ea acceperit bono modo.'

\$\$ 51-4. Quomodo rex et regnum et filii spiritales in eum insurrexernnt. Quomodo summum pontificem adiit, \&c. $=$ Pontigny life, $\S 54$. It will be noticed that both lives pass lightly over the political aspects of Edmund's pontificate. This is only to be expected from their object, which is to edify, and from the materials on which they are based-the evidence, that is, which was collected to justify Edmund's canonisation. For the history of Edmund's difficulties the Cottonian (or Matthew Paris) life and the documents collected by Dom Wallace are the chief authorities. On the subject of the visit to Rome the Pontigny author is more detailed, just as he has more to say than his rival about Edmund's early residence at Paris. There can be little doubt that each consulted the taste of a special audience. The Pontigny writer had French readers in view; the Balliol writer is more insular.

\$55. De primo consilio. An account of the first conference which Edmund held with the bishops about his relations with the king and the legate Otho $=$ Pontigny life, $\S 54$ (latter part). The Balliol life bere gives the fuller account. That it is bere nearer to the common source than the Pontigny life may be seen by reference to the corresponding passage in the third of the lives printed by Dom Wallace."

${ }^{10}$ Op. cit. iii. col. 1909.

"Op. cit. p. 622. 
§§ 56-7. De secrındo consilio, \&c. An account of the circumstances in which Edmund excommunicated the adversaries of Canterbury and finally resolved to leave England. Reproduced in the Pontigny life, $\S 55$. $\S 56$.

\$58. De quodam febricitante per eum sanato = Pontigny life,

\$59. Quomodo apparuit ei beatus Thomas $=$ Pontigny life, $\$ 60$.

$\S \S 60-1$. Quod spiritum prophetie habuit $=$ Pontigny life, $\$ 60$. These sections are important for the light which they throw upon the date of the common source. We are told of prophecies which St. Edmund made to Albert of Köln, archbishop elect of Armagh, and to William Raleigh, bishop of Norwich and bishop elect of Winchester. The narrative, in both texts, concludes by pointing out the truth of these prophecies: 'Nam et ille quondam Armachanus ${ }^{12}$ gloriatur in tribulationibus in quibus adhuc desudat pro iusticia, et ille Wintoniensis post immensos tribulationum aggeres iam de omnibus feliciter triumphat.' William Raleigh was allowed to take up the see of Winchester in 1244; he died in 1250. This passage must have been written between these dates. The reference to Albert as quondan Amachanus narrows the limit of time still further; for he did not resign his see before 1246 .

$\S 62$. De causa exitus eius de Anglia. A brief report of a conversation which Edmund held with the prior and subprior of Lewes on the eve of his departure. These persons are vaguely described in the Pontigny life, $\$ 61$, as quidam vivi religiosi. We know that Edmund was in the neighbourhood of Lewes shortly before he departed from England.

$\$ \$ 63-4$. Dc exitu cius. Dc ingressu eius in Pontiniacum=Pontigny life, $\$ \$ 61-2$.

$\$ \S$ 65-6. De secessu eius apucl Soysi. Quomodo ibidem infirmatur = Pontigny life, $\$ 63$. St. Edmund removed from Pontigny to Soisy during the autumn heat, to obtain a change of air. Here the Balliol life reproduces the actual words of an eye-witness: 'cui cum abbas sancti Iacobi de Provino [Provins] vel prior de Soysi, quis eorum memoric non occurrit, coctana cocta que infirmis offeruntur offerret,' \&c. The Pontigny life mentions only the abbot of Provins.

\$67. Quomodo cxitum sunm nunivit sacramentis ecclesiasticis. Reproduced in Pontigny life, $\S 64$. Contains the last prayer of St. Edmund, 'Tu es, Domine, in quem semper credidi,' \&c., which is quoted in all the other contemporary lives.

\$68. Quomodo se habuerit post perceptionem sancte communionis. This section, reproduced in the Pontigny life, $\$ 64$, gives a fairly correct version of the archbishop's last mot: ' Iubilum quod [MS. que] sensit in corde materno designavit sermone, et Anglico velud ludens proverbio dixit, Men seyeth gamen god [MS. god] on wombe, and i segge mi gamen goo [MS. godt] on heorte. Quod Latine sic exprimit interpres, Dicitur ludus vaclit in ventrem : ego dico, nunc ludus vadit in cor.' The jest is also given in the Cottonian life, ${ }^{13}$ which follows the same source, presumably Bertrand.

\$69. De extrcma iniunctione eizs et dictis eius usque ad mortem. Reproduced in the Pontigny life, $\S 64$. It is characteristic of these two 
lives that they omit the details, which the Cottonian life preserves, respecting Edmund's last will and testament. This latter source quotes a most interesting letter from Edmund to William Raleigh, begging that bishop to act as his executor, 'quia mortui raros et paucos invenire solent amicos, et maxime in regno Anglie. ${ }^{14}$ Of such terrestrial details the Balliol and Pontigny authors are oblivious.

It is scarcely necessary to give an analysis of the remaining sections (§§ 70-8) in the Balliol life. They deal with the burial and translation of the saint and recount some miracles. It is the same story, with some variations, which we find in the Pontigny life, $\S \S 64-71$.

The general conclusions which may be drawn from our analysis of these two lives are not, historically, of great importance. The Balliol life does not add much to our knowledge of St. Edmund, but it does help us towards the partial settlement of a vexed question in the criticism of the sources. There has been much discussion as to the authorship of the Pontigny and Balliol lives and the other lives of the saint which we have cited. One can only marvel at the assurance with which the names of Robert Rich, Bertrand of Pontigny, and Robert Bacon have been attached to this or that life. The only one of the biographies which can be ascribed with sume confidence to a specific author is the Cottonian MS. Julius D. vi. In this case internal and external evidence converge to the conclusion that Matthew Paris is the author. ${ }^{15}$ The problem is much more difficult in the case of the other lives, where we have to rely upon internal evidence alone. The general parallelism of the Balliol and Pontigny lives is sufficient to show that they are not merely founded upon a common stock of documents, but that the material had been carefully selected, and to some extent arranged, before they began to worl. At the same time it is clear that neither these writers nor the compiler whom they followed made any serious attempt to recast the selected material. The method of all three was the same; they copied striking extracts with a running flow of the conventional moralisations. The Pontigny writer was on the whole more literary than the author of the Balliol text; but even the Pontigny text only shows tentative and spasmodic attempts at originality. The differences of the two texts are greater than the foregoing analysis reveals; the Pontigny life includes a fair number of anecdotes which the other suppresses. But there is no reason to think that either writer contributes anything of importance from his own knowledge. The compiler from whom both drew is a more tantalising problem. How much of what he recorded was his own experience? All we can safely say is that he was a chamberlain in the archbishop's household, who

14 Wallace, p. 575.

is Baroness de Paravicini, op. cit. p. zxxi ff.; B. Ward, St. Edmund, Archbishup of Canterbury, p. 242. 
knew little of public affairs, and who was so indolent or so humbleminded that he lost no opportunity of quoting others for facts of Edmund's life and traits of Edmund's character which must have come within his own range of observation. He knew little about the early life of his patron, much less than his fellow-servant Eustace of Canterbury, whose deposition supplied Matthew Paris with material for the earlier part of the Cottonian text. ${ }^{16}$ But the chamberlain's narrative of Edmund's last moments appears to have been the recognised authority for an episode of history which appealed most strongly to the feelings of Edmund's contemporaries. Matthew Paris is the only other biographer who adds anything to our knowledge of the saint's dying words and deeds. The other lives read at this point like abridgments or imperfect reminiscences of the chamberlain. Probably we may identify the chamberlain with Bertrand of Pontigny; but the attribution of a name adds, in this case, little or nothing to our knowledge of the author's personality.

The Pontigny life and the Balliol life may, then, be considered as mutually independent recensions of one life. The ultimate sources of Bertrand's work, apart from his own reminiscences, were apparently the depositions collected for the process of canonisation. No doubt Bertrand himself wrote such a deposition. The frequent echoes of the Pontigny and Balliol lives which we find in others written not much if at. all later in date are to be explained by the recourse of all the authors to the same official letters and depositions. At all events this hypothesis can be verified in the case of the life by Matthew Paris, whose sources happen to be known. Such being the method on which the hagiographers performed their work we may plead for greater attention to their evidence than is usually accorded by critical historians. The hagiographers seem, if we may judge from these examples, to have followed the best obtainable evidence without allowing much licence to their imagination or to their preconceived ideas of sanctity. They tell us with considerable fidelity what was asserted and believed by the personal friends of the saints; and where the flowers of rhetoric are strewn over the narrative it is not a rhetoric which suppresses or transforms the essential features of the story as it was known to the writer.

H. W. C. Davis.

${ }^{16}$ See Wallace, p. 